\title{
PERAN PEMBANGUNAN POLITIK TERHADAP PEMBANGUNAN NASIONAL
}

\author{
1) Dwi Antoro, ${ }^{2}$ ) Riska Defiana Sari, ${ }^{3}$ ) Anita Trisiana \\ 1,2) Mahasiswa Akuntansi Universitas Slamet Riyadi \\ 3) Dosen PPKn Universitas Slamet Riyadi
}

\begin{abstract}
ABSTRAK
Penelitian ini bertujuan untuk mengetahui bagaimana peranan pembangunan politik terhadap pembangunan nasional. Sistem politik di indonesia sekarang terjadi demokratisasi, kondisi bisa mengakibatkan macam-macam tanggung jawab kepada dinamika kehidupan politik, nasional, tetapi jugapada dinamika sistem lain yang menunjang suatu kenegaraan. Metode dalam penelitian ini, menggunakan metode deskriptif. Dalam pembangunan itulah yang dimaksudkan supaya bisa mempertahankan keutuhan indonesia dan juga semakin memper erat persatuan dan kesatuan bangsa. Agar bisa mewujudkan kesejahteraan dan keadilan kepada semua masyarakat indonesia. Selain itu juga kita harus bisa dapat memanfaatkan teknologi yang ada secara baik agar bisa bersaing dalam menghadapi masalah globalisasi dan juga agar mencerdaskan bangsa dan mampu meningkatkan suatu kesadaran politik. Berhasilnya pembangunan politik agar demokratis itu juga tidak di pengaruhi dalam kondisi yang berkembang di dalamnya saja, akan tetapi juga dipengaruhi pada kondis politik di internasional. Hal yang lain dalam sebuah keberhasilan pembangunan sistem politik yang demokratis perlunya dukungan pada penyelenggara negara yang profesional dan bebas dari koruptor, kolusi, dan nepotisme.
\end{abstract}

Kata kunci : Persatuan, Politik, Pembangunan Nasional

\begin{abstract}
The objecyive of the research was to find out the role of the political development in the national development. Political system in Indonesia has experiencing democratization, which brings various consequences not only the dynamics of political national life, but also the dynamics of the another system which supports the implementation of the state life.The development of a democratic political system is directed to be able maintain the territorial intregity of Indonesia and further strengthens unity of Indonesia which provides an increasingly broad space for the realization of the equitable justice and the prosperity for all Indonesian people.Besides that, we must also to be able to utilize the advances in information dan communication technology optimally in order to strengthen competitiveness in faced global challengs and in the efforts to educate the nations life and increase people's political awareness. The success of the democratic political development system is not only influenced by the situation that develops in the country, but also can be influenced by the international political situation. Besides that, the success of the development of a democratic political system needs to supported by professional state administrations who are free from practise of the corruotion, collusion and nepotism, than can optimally utilize various forms of mass media and broadcasting as well as various information networks inside and outside the country.
\end{abstract}

Keywords : Unity of the Nations, Politics, National Development 


\section{PENDAHULUAN}

Di indonesia pada saat ini sistem politiknya sedang terjadi demokratisasi bisa amat menjadi macam-macam permasalahan melainkan juga pada dinamika pada kehidupan politik indonesia, tapi juga pada dinamika sistem yang lainnya. Sistem politik di negara republik indonesia pada saat tengah pada 1960-an hingga saat ini, Stabilitas politik dipercaya sebagai dasar dalam berpikir nyata pada susunan taktik perkehidupan negara dan masyarakat di tanah air.

Stabilitas politik sebagai konsep bersama teori yang melatarinya, dipergunakan sebagi metode atau kerangka untuk memahami sebagian dari keseluruhan proses politik di indonesia sebagai suatu sistem. Ukuran bagi keberhasilan kekuatan-kekuatan politik untuk merealisir peranannya tersebut tidak hanya dilihat dari apa yang dicapai, akan tetapi sekaligus dipandang pula melalui akibat dari proses pencapaian atau interaksi antar kekuatan-kekuatan tersebut. Berhasilanya suatu suatu untuk membangun tidak saja pada pengaruh keadaan yang bermekar diindonesia, tapi dipengaruhi juga pada pengaruh politik diinternasional. sesuai pada hubungan politik diluar negeri, maslah utama dihadapi yakni belum adanya persiapan diIndonesia pada persiapan macam-macam dunia politik dan ekonomi dan lambatnya negara kita pada permainan dunia.

Untuk menjamin ketstabilan politik, maka sistem partai diubah dengan menyederhanakan jum;lah partai atau kekuatan politik yang dapat bertarung dibidang politik secara syah. Disamping itu sistem politik lebih mendorong munculnya kepemimpinan yang moderat didalam kekuatan-kekuatan politik yang ada. Lalu diusahakan mendekatkan jarak ideologis diantara partai politik dengan memberikan penafsiran yang manunggal terhadap ideologi negara pancasila. Dengan demikian, penafsiran terhadap pancasila yang dilandaskan kepada ideologi partai dicoba dihinndarkan.

Diatas landasan kestabilan politik seperti itulah pembangunan ekonomi dilaksanakan dengan kesejahteraan sosial bagi masyarakaat indonesia sebagai tujuan akhirnya.

\section{METODE :}

Metode yang digunakan adalah metode penelitian deskriptif. Metode penggambaran bisa dijelaskan yaitu langkah-langkahmemecahan permasalahan yang diperiksa melalui penggambaran kondisi subyek atau obyek didalam penelitian bisa seperti manusia, lembagalembaga, dan masyarakat. 
Pendapat Nazir (1988:63) metode deskriptif adalah metode untuk penelitian status kelompok orang, pada obyek, dalam keadaan, pada sistem pemikiran atau suatu kelas kejadian saat kini. Tujuannya dalam penelitian ini yaitu sebagai pembuatan penggambaran, ataupun lukisan secara tersusun, nyata dan tepat tentang fakta, sifat-sifat beserta berhubungan antara peristiwa yang diperiksa. Menurut Sugiyono (2005:21) mengutarakan metode deskriptif yakni suatu metode yang berguna sebagai penggambaran / pemecahan dalam hasil penelitian tapi tidak dipergunakan dalam pembuatan kesimpulan. Menurut :

Whitney (1960: 160) metode ini yaitu pencarian faktual dan penjelasan yang aktual. bisa dibilang yaitu penelitian ini adalah penelitian yang berusaha menjelaskan dalam suatu masalah, kejadian yangadai dimana sekarang ini atau masalah yang tepat.

\section{PEMBAHASAN}

\section{Pendekatan Pembangunan}

Terhadap Sistem politik

\section{a. Sistem Politik}

ISTILAH "sistem politik" telah menjadi sangat lazim dipergunakan dalam judul buku teks atau dalam berbagai macam karangan dibidang ilmu politik perbandingan. Bukubuku teks lama mempergunakan istilah 'pemerintah", 'bangsa', atau "negara" dalam menguraikan apa yang kita sebut suatu sistem politik.

Konsep "sistem politik" telah dipakai secara meluas karena mengarahkan perhatian pada seluruh cakupan kegiatan politik yang ada dalam sebuah masyarakat, terlepas dibagian masyarakat mana kegiatan-kegiatan tersebut berada.

Easton berbicara tentang alokasi nilai-nilai dari yang berwenang; Lasswell dan Kaplan tentang keterampasan (deprivasi) gawat; Dahl tentang kekuasaan, aturan dan otoritas. 1Dalam keseluruhan definisi tersebut tercermin legitimasi, sanksi berat; kekuasaan yang berhak untuk menghukum, menjalankan, memaksa. Kita setuju dengan Max Weber ${ }^{2}$ yang mengatakan bahwa kekuatan yang sah adalah unsur yang dapat dari seluruh, tindakan sistem politik, yang memberikan kepadanya kualitas khusus dan penting, dan juga keutuhannya sebagai suatu sistem. Pemegang otoritas politik, dan hanya mereka, mempunyai hak yang secara umum dapat diterima untuk memaksa dan memperoleh kepatuhan berdasarkan kekuasaan yang sah tersebut. (kekuatan adalah 
'sah' kalau terdapat keyakinan akan kebenaran penggunaannya).

Sistem politik tidak tidak hanya meliputi lembaga-lembaga pemerintahan, seperti badan legislatif, pengadilan dan badan administrasi, tetapi semua struktur yang ada aspek politiknya. Diantara struktur tersebut terdapat struktur tradisional seperti pertalian keluarga, kelompok kasta; dan gejala anomik seperti pembunuhan pemimpin, kerusuhan dan demonstrasi; serta organisasiorganisasiformal seperti partai politi, kelompok kepentingan media komunikasi.

Aspek kedua dari konsep "sistem"'adalah gagasan tentang batas sebuah sistem bermula dari suatu tempat dan berhenti padaa suatu tempat pula. Bila kita melihat organisme atau sebuah mobil, sangatlah mudah menentukan batasnya dan mengetahui interaksi antara sistem tersebut dengan lingkungannya.

\section{b. Struktur dan Budaya}

$$
\begin{aligned}
& \text { Istilah-istilah 'struktur', dan } \\
& \text { 'budaya" juga sangat penting } \\
& \text { dalam skema analisis kita. Struktur } \\
& \text { adalah seluruh aktivitas yang dapat }
\end{aligned}
$$

diamati yang membentuk sistem politik. Salah satu unit dasar dari sistem politik adalah peran politik. Kita mengacu pada suatu perangkat peran-peran khusus yang berhubungan satu sama lain sebagi struktur-struktur. Jadi penghakiman adalah peran, pengadilan adalah sebuah struktur dari peran-peran. "peran" dan 'struktur" mengacu pada tingkah laku para individu yang dapat diamati. Aturan-aturan hukum dan norma-norma hukum ideal dapat mempengaruhi tingkah laku tersebut, tetapi jarang menguraikan tingkah laku secara lengkap.

\section{c. Input dan output}

David Easton, seorang ilmuan politik yang pertama menganalisis politik secara benar-benar sistematik, membedakan dua tipe input kedalam sistem politik : tuntutan-tuntutan dan dukungandukungan.

Berikut klasifikasi yang mengilustrasikan lingkup dan ragam tuntutan sistem politik :

1. Tuntutan akan tersedianya barang-barang dan jasa, seperti gaji dan aturan-aturan jam kerja, kesempatan pendidikan, fasilitas rekreasi, jalan-jalan dan transportasi. 
2. Tuntutan akan pengaturan tingkah laku, seperti tuntutan akan keselamatan umum, kontrol terhadap pasar, peraturan mengenai perkawinan, kesehatan dan sanitasi. 3. Tuntutan untuk berpartisipasi dalam sistem poitik-hak untuk memilih dan dipilih, mengajukan petisi kepada badan-badan pemerintahan dan pimpinannya, dan untuk mengorganisir asosiasiasosiasi politik.

4. Tuntutan akan komunikasi dan informasi, seperti permintaan dan penegakan norma -norma, diberitahukannya maksud kebijaksanaan elite pembuat kebijaksanaan , atau pameran keagungan dan kekuasaan dari sistem politikdalam waktu-waktu terancam atau pada peristiwa seremonial.

Arus input dan output termasuk transaksi antara sistem politik dengan komponenkomponen dari lingkungan domestik dan asing, dan input dapat saja datang dari salah satu dari tiga sumber ini -masyarakat domestik, para elit politik dan lingkungan internasional.

\section{d. Aspek-aspek fungsional sistem politik}

Fungsionalisme adalah sebuah tema lama dalam teori politik. Dalam bentuknya yang modern, penekanan pada fungsionalisme diambil dari antropologi dan sosiologi. Para pemuka teori sosial yang berhubungan dengan fungsionalisme adalah antropologmalinowski dan Radcliffe-Brown dan sosiolog parsons, Merton dan Marien Levy. Meskipun mereka berbeda secara mendasar dalam konsep-konsep tentang sistem dan fungsi, secara essensial mereka mengatakan bahwa kemampuan untuk menjelaskan dan memprediksi dalam ilmu sosial itu melakukan fungsi-fungsi dalam sistem. Dengan membandingkannya kita dapat menganalisis sistem-sistem yang tampak sangat berbeda satu dengan yang lainnya.

Beberapa sistem politik terutama adalah regulatif dan ekstraktif. Sistem totalitarian menekankan tuntutan yang datang dari lingkungan internasional. Pada saat yang sama sistem tersebut mengatur dan memaksa perilaku dalam masyarakatnya, dan berusaha menarik sumber-sumber 
daya yang ada secara maksimum dari penduduknya. Totalitarianisme komunis berbeda dengan totalitarianisme fasis yaitu memiliki juga kapabilitas distributif yang kuat. Ini berarti bahwa sistem bahwa sistem politik itu sendiri seccara aktif memindahkan sumber-sumber daya dari beberapa kelompok penduduknya ke kelompokkelompok lainnya.

\section{e. Pembangunan Sistem politik}

Peristiwa-peristiwa yang mendorong ke arah pembangunan politik berasal dari lingkungan internasional, masyarakat, ataupun dari elite- elite politikdalam sistem politik itu sendiri.

Keinginan untuk melakukan pembangunan politik mempunyai konsekuensi keterlibatan beberapa perubahan penting. Pembangunan berakhir ketika struktur dan budaya sistem politik tidak mampu mengatasi masalah atau tantangan yang dihadapinya tanpa kelanjutan diferensiasi struktur dan sekularisasi budaya. Masyarakat tradisional dan maju juga mungkin memperlihatkan keruntuhan struktur modern yang terdiferensiasi dan dominasi dari himbauan serta sikap tidak rasional ketika rintangan menjadi sangat besar.

Problem pembangunan negara dapat timbul dari sebuah ancaman terhadap kehidupan sistem politik yang berasal dari lingkungan internasional. Hal tersebut dapat juga muncul dari ancaman yang berasal dari masyarakat dalam bentuk tekanan revolusioner yang menantang kestabilan atau kelangsungan hidup sistem politik. Atau hal ini juga juga merupakan hasil perkembangan tujuan-tujuan baru diantara elite politi, misalnya ekspansi nasional atau penciptaan sebuah kehidupan istana yang bermewah-mewah.

\section{Pembangunan Lembaga Sebagai} Pandangan dan Usaha : Suatu Tinjauan

a. Pembangunan Lembaga Sebagai Argumen Tentang Perspektif

Yang dimaksud dari diatas adalah suatu usaha untuk menempatkan perspektif dalam perspektif-yakni mempelajari dan menilai beberapa argumen tentang pembangunan lembaga, dan untuk mencatat dan mempertimbangkan beberapa implikasi dan kemungkinan perluasan argumen tersebut. 
'Argumen' yaitu sislsilah paling benar pada pendapat untuk membangun lembaga. PL mengutarakan yakni :

a. Teknologi merupakan kunci, bahkak bisa menjadi utama kunci, dalam untuk membangun

b. Mendirikan kelompokkelompok secara baik merupakan permasalahan utama dalam alat sebagai penyampaian teknologi

c. Faktor-faktor normatif yaitu permasalahan genting didalam pembangunan kelompok dalam penyampaian teknologi dan hasil untuk mengembangkannya.

b. Pembangunan

Lembaga Sebagai Teori

Pembangunan lembaga bukan hanya suatu teori (terkecuali dalam arti yang luas dan paling metaforis dari kata yang banyak disalahgunakan itu).

Perspektif mengemukakan bahwa ada sesuatu yang dapat disebut ''kelembagaan'. Ia menegaskan bahwa sifat ini dapat merupakan suatu segi dari organisasi-organisasi.

Yang dipandang sebagai sistem-sistem terbuka. Ia mencatat bahwa untuk untuk mencapai sifat yang berharga ini, haruslah ada jenis kepemimpinan, kait-kaitan dan seterusnya "'yang tepat'.

Golongan fenomena yang ditangani pembangunan lembaga berbeda dengan kelompok bahan ilmu-ilmu eksakta (pasti). Hal ini bukanlah untuk menyangkal bahwa asumsi-asumsi tentang keteraturan dan interaksi dapat dengan segera diterapkan untuk fenomena sosial. Dan juga bukan untuk menyangkal kemungkinan untuk membuat teori tentang pelembagaan. Yang hanya ingin dikemukakan adalah bahwa ada perbedaan antara pernyataan-pernyataan "seakan-akan"' dan pernyataan-pernyataan

"'bila/maka" dan bahwa pernyataan-pernyataan tentang pembangunan lembaga, yang dirumuskan seakan-akan teoretis, tidaklah perlu merupakan jenis pernyataanpernyataan ' 'bila/maka'yang mengajukan jenis penjelasan 
terteentu.- yakni, penjelasan yang teoretis.

\section{Pembangunan Politik di}

\section{Indonesia}

Pembangunan politik merupakan bagian dari pembangunan nasional, diman pembangunan itu ditunjukkan untuk mewujudkan masyarakat yang demokratis sehingga terciptanya suatu ketertiban politik.

Pada zaman dulu manusia dihadapkan berbagai macammacam perubahan yang nyata dimana ia hidup. Lama-kelamaan, peristiwa tersebut merubah jadi beda yang terjadi didalam makhluk hidup

Evolusi artinya membuka gulungan atau membuka lapisan yang berasal dari bahasa latin. Didalam revolusi, perubahan yang terjadi dapat direncanaka dan dijalankan tanpa melalui sebuah kekerasan.

Kemiskinan dan kelaparan mempunyai hubungan sangat erat dengan demokrasi. Pendapat sen represi hal inilah bisa menjadi penghamba pertumbuhan ekonomi. Kelaparan secara substansial tidak akan pernah terwujud dinegara manapun yang independen.
Menurut pye, dalam pembangunan politik berkaitan dengan masalah partisipasi dalam kegiatan- kegiatan politik secara demokratis maupun totaliter.

4. Politik, Pembangunan dan Kesejahteraan Masyarakat

a. Politik dan Pembangunan Ekonomi

Didalam kehidupan politik dan ekonomi tidaklah bisa memisah diantaranya tapi sebgai kepentingan penjelasan perlunya memperhatikan keduanya untuk subsistem yang memiliki sifat dan fungsi sendiri. kalu bangsa dalam sistem politiknya mempunyai unsur penting 'pengguunaan kekuasaan secara syah" ddalam perbatasan tanggung jawaban pada rakyat secara menyeluruh, sehingga perekonomian untuk sistem adalah pengelompokan untuk memenuhi kebutuhan rakyat pada jasa dan barang bisa nya ada secara susah untuk dicari.

Hubunganny sistem tersebut terletak dalam menggunakan ' kekuasaan memaksa secara syah'didalam usaha untuk memenuhi kebutuhan-kebutuhan rakyat. contohnya dalam untuk 
merencanakan dan mengarahkan rakyat dalam pusat usaha perekonomian biasanya dinamakan membangun, adalah sebagai dari hubungan amat kuat sekali dalam politik dan ekonomi. Banyaknya hubungannya, yaitu beda di macam-macam bangsa. tapi di tanah air, sama juga di bangsabangsa berkembang biasanya; Hubungan antar politik dan ekonomi sangat kuat

. Ada beberapa faktor yang menyebabkan hal itu :

- Bangsa yang setelah terlepas pada sistem perekonomian kolonil pada sistem perekonomian memecah pada 2 unsur yakni ekonomi ekspor dan yang berhubungan pada hasil barang-barang yang berguna dinegeri Belanda

- Sebagai konsekuensi dari sistem perekonomian penjajahan pada rakyat sangat memusat pada sektor hasil tani, sehingga hasil peindustrian dan dagang menengah / perantara pada hasil ekspor sungguhlah melemah

- Pengorganisasian perekonomian yang setelah bertumbuh itu dapat melemah derajatnya dalam persaingan dengan organisasi perekonomian yang sudah memiliki peristiwa penghubung didalam sistem perekonomian kolonial.
- Secara nasional organisasi-organisasi perekonomian yang telah adanya dalam rakyat tidak bisa memperhatikan sendirinya sebagai kelompok politik berdasarkan pada unsur primodisi dari jumlah perekonomian antar didaerah perekonomian, sangat mempengaruhi pada hubungan antar didaerah dan juga hubungannya dengan pusat dan didaerah sebagai kesatuan perekonomian.

Seluruh faktor tersebut melihatkan terdapatnya butuh suatu pengelompokkan diantaranya ekonomi masyrakat diindonesia secara menyeluruh. Mengenai itulah yang menyebabkan tergantungnya kelompok perekonomian baik daripada organisasi-organisasi perekonomian, ataupun didaerah perekonomian dari peran pemerintah didalam ekonomi. Disusul adanya kalau dilihat yakni "peran pemerintah didalam abad ke-20 amatlah mengikat kepada kesatuan perekonomian secara nasional, Adanya sistem hukum nasional, disingkirkannya rintanganrintangan terhadap aktifitas ekonomi masa kini misalnya memberikan usaha yang mempunyai keterampilan, pengembangan transport dan komunikasi, dan bisa digunakan efektif penguasaan ataupun anggota pemerintahan bangsa dalam peningkatan aktifitas perekonomian secara nasional "

menyangkut tentang ekonomi, pada dasarnya dikenal tiga usaha pokok yaitu : 
- Pengaturan kegiatan perekonomian secara menyeluruh melewati berusaha dilandasi berkembangnya perekonomian, ditekankan untuk pengangguran, dan merawat seimbangnya harga. sehingga langkah yang didapat yaitu untuk pengaturan seimbangnya antara penerimaan pemerintah lewat pajaknya pada pembelanjaan pemerintah.

- Pembagian kembali untuk membangun indonesia kepada rakyat lewat pajak progresif, sumbangan-sumbangan, dan subsidi berupa jaminan sosial (social security) bagi yang menganggur, menderita cacat, kecelakaan dan lainlainnya.

- Menyediakan prasarana ekonomi.

Jika kita perhatikan tugasnya diatas di dalam pelaksanaan, maka kita akan berpikiran cepat terbentur pada besarnya tuntutan dalam melayani masyrakat. Rakyat didalam penjelasan swasta setelah memiliki keahlian yang sedikit dalam peran pada pihak yang menyiapkan segala macam peralatan ataupun kebutuhan yanga ada.

Bangsa ini mempunyai kemampuan dalam jadi negara yang makmur. Peristiwa pada banyaknya bangsa lainnya membuat kita yakin bahwasanya tidak panjang waktu yang dibutuhkan dalam jadi bangsa yang makmur. Cukup dengan 30 tahun, Korsel pada mulanya negara feodal dan tradisional dengan sistemnya perekonomian, politik, dan hukum hancur karena peperangan umat ditahun 1950-1953, yang bisa menjadi bangsa masa kini yang makmur pada masa Park Chung Hee, yang bisa memperoleh hormat dari internasional sehingga jadi tuan rumah Olimpiade.

Malaysiaa secara sosialnya berbeda seperti negara indonesia, dan setelah merdeka ditahun 1957, saat ini sudah jadi negara GNP perkapita pertahun 4.000 dolar Amerika serikat. Hal lainnya, untuk bisa pengangkatan prestise bangsa dimata internasional, Bangsa ini telah membuat gedung adalah gedung ter-tinggi didunia.

Bangsa yang bisa waktu sedikit untuk bisa memajukan, ada yang dapat melangkahi perubahan dipolitik paling bawah, misal china setelah pemimpinan Deng Xiao Ping dan Jiang Zemin. Pengajaran pada berhasilnya bangsabangsa diinternasional, yakinkan bangsa ini bahwasanya dalam pembangunan sejahtera ditanah air, perlunya muncul kehidupan dipolitik yang baik dalam menegakkan hukum tegas.

Kandungan yang terpenting didalam membangun politik adalah mengembangkan penghidupan secara demokrasis. kemajuan demokratis ditanah 
air diwarnai dengan Pemilihan umum 2004 ditandai pada macam-macam berbagai perihal. Pertama-tama, berkurangnya kapasitas parpol calon pemilihan umum legislatif pada 48 partai diPemilihan umum 1999 jadi 24 partai diPemilihan umum 2004, melangkahi cara demokratisasi, seperti syarat-syarat diketatkan masanya pada setiap parpol. menyusutnya kapasitas parpol itu, ditujukan supaya bisa dalam pengembangan tahapan politik yang sangat terbaik.

majunya kedua, diwarnai pada dibuatnya pilihan aparat DPD lewat langsung pilih orangnya, meskipun tetap banyaknya yang persoalkan untuk menetapkan kapasitas wakil yang setara dalam tiap-tiap diprovinsi banyaknya 4 orang,tidak persoalkan berapapun kapasitas masyarakat dan besarnya wilayah disetiap wilayah suatu daerah. majunya bisa dilihat pada pilihan presiden dan wakilnya lewat langsung dari masyarakat, secara baik.

Tahapan majunya demokratis ditanah air selanjutnya, diwarnai pada lahirnya macam-macam kreatifitas dan aktifitas rakyat dalam pencegahan lahirnya politikus pembuat masalah dilembagalembaga politik ditanah air ini. meskipun efektifitas tidak efisien, tahapan ini, adalah kemajuan yang dimaksudkan supaya bisa mendapatkan orang-orang yang menempati dilembaga-lembaga politik ditanah air adalah primus interpares, amat baik. cuman hal itulah lembaga politik ini bisa mendapatkan hasil-hasil politik berkualitas. Pengawas aktif pada masyaraat didalam tiap tahapannya, bisa membaikkan macam-macami menyimpang sudah terlama jadi didalam macam-macam politik ditanah air, seperti tahapan saringan kader yang belum didasarkan sistem merit dan ditandai nepotisme serta kolusi, tahapan ini dilandasi pada uang politik pada hasil-hasil hukum kepentingan organisasi pada pengorbanan dalam kepentingan tanah air.

Dalam usahanya dalam pembangunan sistem politik yang efisien, dimana pun, karenanya adalah tarif yang perlu dibayarkan didalam penciptaan kematangan teratur diatas keseluruhan diikatan sistem perekonomian, sosial, politik, dan budaya pada rakyat yang maju. mahalnya dikarenakan ia merupakan tarif perlu dibayarkan dalam pembangunan demokratisasi, selebihnya pada rakyat terdapat kedudukan benar berbudaya feodal dan paternalistik, sama halnya ditanah air.

Banyaknya masyarakat internasional belum bisanya melepas kurungan otoritarianisme dan diktatorisme demokratisasi yang tenang. bisa disaksikan jumlahnya bangsa yang terperangkap 
dalam tahapan politik yang sentralistik dan represif.

Berubahnya kuasa ditanah air pada masa Tunggul Ametung-Ken Arok, Amangkurat I, hingga ini sedikit kejadian. Diera tanah air merdeka adanya Orde Lama, Orde Baru, dan Orde Reformasi. Bergantinya Soekarno dan Soeharto, terus Habibie, kemudian Abdurrahman Wahid setelah Megawati, sudah terlibat lewat pada cara terkhusus. Semua orang dapat melihat penyesalan mayarakat Afghanistan cinta bangsanya, pada putusan elite politik sudah melaksanakan dalam untuk merubah lewat tahapan politik belum baik.

Afghanistan saat itu merupakan bangsa kerajaan yang tentram walaupun tidak mampu, perintah pada Raja Zahir Syah. kemudian para elite

politik telah merubah jadi bangsa republik, dalam penuh harap supaya dapat melakukan pembangunan bangsa yang maju yang damai. Tapi, didalam tahapan sudah memunculkan ketidakseimbangan pada perebut penguasa antara pemimpin yang membawa kuat di luarnya, yang berlalu buka masalah intervensi bangsabangsa luas; misalnya AS, Rusia, china, India, Pakistan, dan Iran. Hingga sekarang Afghanistan tentu sekarang terjebak didalam keburukan sosial, ekonomi, dan politiknya yang panjang, sudah langsung lebihnya 30 tahunan.
Prosesnya pengganti pemimpin disuatu bangsa mana saja didunia, supaya bisa berjalan dengan tenang melewati cara pemilihan umum secara demokratisasi, dimana harapan-harapan untuk merubah bisa ditempatkan agar teratur. Perjalanan setiap orang sebenarnya sebaiknya makin buat kedewasaan didalam bangsa, dan pada pengantar untuk merubah yang baik.

Politiknya bisa mahal dikarenakan ia merupakan tarif perlu dibayarkan dalam pembangunan sejahtera dan berlanjutnya untuk membangun. Bangsa ini merupakan sangat banyak biaya-biaya politik yang tertutup, belum terlihat, banyaknya elite politik belum menggunakan mekanisme efisien dalam mendapatkan keinginan politik. Lumpen borjuasi merupakan tempat perjudian, penyelundupan, korupsi, banyaknya dalam pembiayaan politik memang upahnya seperti payung untuk berlindung. Didalam penyelenggaraan membaikkan penghidupan politik dan lembaga politik ditanah air, semestinya menjadi tempat pembiayaan politik setiap rakyat ingin kedepan jadi pimpinan politik disetiap tingkat, dilaksanakan terlihat.

Supaya ditanah air bisa mendapatkan sejahtera didalam masa sangat singkat, perlunya hadir pemimpin macam-macam tingkatan, ditingkat indonesia dan lokal, yang bisa merubah sekalian dapat dibuka masyarakat, yang bisa sebagai penggerak dan membaikkan macam-macam 
kemampuan yang ada, bisa untuk penyusunan pemograman yang visioner yang efektif didalam waktunya, dan menggerakkan langkahnya dengan baik dibawah pemimpin yang tidak itu saja wibawa, tapi percaya, jujur,dan bisa menumbuhkan dan mengembangkan matang-matang dan persiapan masyarakat dalam merubah. Oleh karenanya, tiap pilih pemimpin, harus dibukanya seluas-luasnya gerbang untuk masuk kader-kader negara baik dalam mampu bisa memilih langsung pada masyarakat langsung demokratisasi. Yang lainnya, Dewan perwakilan Rakyat perlu percaya didalam wakili pendapat masyarakat dan bisa untuk pengawasan disebuah pemerintah, kalau pemerintah dan kekuasaannya tidak diawasi dengan baik tentunya bisa memang terjadi penyimpangan.

Adanya bukti aktual diinternasional, sebagai pengajaran untuk semua bahwasanya macam-macam baik disuatu pada sistem, untuk mengangkat masyarakat untuk pencapaian tujuan dalam pembangunan negara sejahtera, bangsah kuat, dan damai. Didalam negara peran kepemimpinan sangatlah menjadi penentu. Kong $\mathrm{Hu} \mathrm{Cu}$ mengajari pada semua bahwasanya seseorang pemimpin bagai angin, dan masyarakat bagai rerumputan. setelhnya, dimanapun angin berhembusan, disanalah rerumputan merebahkan daunnya.
Mudah-mudahan peningkatannya keikutsertaan semua rakyat pada macammacam tahapan politik, munculnya kuat dan semangat baru berbangsa hingga berubah jadi negara tanah air pada masa kini yang ada didalam badai macammacam permasalahan, bisa jadi negara makmur serta peradaban besar, dan dapat jadi setara pada bangsa lain disdunia.

\section{Penutup}

\section{Kesimpulan}

Menurut pengertian tersebut bisa dijelaskan yakni Sistem politik kita ini lagi terjadi demokratisasi yang amat mengakibatkan macam-macam sebab bukan itu saja pada perubahan perkehidupan politik diindonesia, tapi bisa pada perubahan sistem lainnya yang mempengaruhi penyelenggara perkehidupan negara. Sistem politik kita ini setelah ditengah tahun 1960-an hingga kini, Stabilitas politiknya sudah diakui bagai bagian dari dasar berfikir baik terhadap susunan taktik perkehidupan negara dan masyarakat ditanah air.

Stabilitas politik bagai ruang dengan pelajaran menempatinya, digunakan untuk langkah ataupun sebagai pemahaman pada seluruh prosesnya dipolitik ditanah air dalam sistemnya. 


\section{Saran}

Dinegara kita sistem politiknya terjadi demokratis, bisa memberikan macam-macam akibat bisa belumnya pada perkehidupan politik diindonesia, tapi hanya pada pengaruh sistemnya yang lainnya bisa mempengaruhi penyelenggara perkehidupan negara.

Untuk membangun sistem politiknya demokratisasi itu dituntut supaya bisa pertahankan utuh wilayahnya

\section{Daftar Pustaka}

Cahyono, Cheppy Hari. (1988).

Ideologi Politik. Yogyakarta : PT. Hanindita Offset

Eaton, Joseph W. (1986). Pembangunan Lembaga dan Pembangunan Nasional. Jakarta : Universitas Indonesia Press

Hanapiah, Pipin. (2001). Pancasila

Sebagai Paradigma. Jurusan

Ilmu Pemerintahan UNPAD

Muhaimin, Hendro. (2013).

Indonesia Now. Between

Pancasila and Crisis of

Democracy in Indonesia.

International Jurnal for Public

Management and Politic

Devolopment

Mutaqin, Zeen Zaenal. (2017). The Story State and Pancasila : dan semakin erat kesatuan dinegara kita yang bisa meletakkan ruangnya yang makin meluas pada wujudnya, adil dan sejahtera semuanya pada semua masyarakat ditanah air.

Sehingga alangkah baiknya dalam penjaminan stabilnya politik, sehingga sistem partainya mengubah untuk sederhanakan kapasitas partainya atau kekuatannya yang bisa bersaing pada bidang politiknya yang baik.

Reflecting Human Rights in The Indonesian Democracy. International Jurnal of The Strong State and Pancasila : Reflecting Human Rights in The Indonesian Democracy Samit, Arbi. (2002). Sistem Politik Indonesia. Jakarta; PT. Raja Grafindo Persada

Siregar, Amir E. (1991). Arus Pemikiran Politik. Yogya; PT. Tirta Wacana

Valiana, Anna dan Anita Trisiana. (2016). Analisis strategi komunikasi politik terhadap partisipasi politik pemenangan Rudi dan Purnomo dalam Pilkada 2015 kota Surakarta. Jurnal Global Citizen, Folume 2 Nomor 2

Weatherbee, Donald E. (1985). Indonesia in 1984; Pancasila, 
Politics, Power. International

Jurnal of University of

California Press

Yuliani, Dian dan Sugiaryo. (2016). Hubungan Kesadaran Politik dan Civic Disposition dengan Partisipasi Politik
Pemilu pemula dalam Pilkades di desa Klodran kecamatan Colomadu Kabupaten Karanganyar tahun 2016. Jurnal Fakultas Keguruan dan Ilmu Pendidikan Universitas Slamet Riyadi 